\title{
Discussion on Innovation of Ideological and Political Education Work of Universities in the "Cultural Feedback" Era
}

\author{
Yanping $\mathrm{Lu}$ \\ Tangshan College \\ Tangshan, Hebei, China, 063000 \\ e-mail: 54518320@qq.com
}

\begin{abstract}
The rapid development of internet brings human society to the era of "Cultural Feedback", which has a profound impact on the work of ideological and political education of universities in new era. The author first explained the profound connotation of "Cultural Feedback", and then analyzed the opportunities and challenges that "Cultural Feedback" brings to ideological and political education of universities, mainly exploring methods and strategies of innovating ideological and political work of universities under the background of "Cultural Feedback" from six points of view.
\end{abstract}

Keywords-ideological and political education of "Cultural Feedback"; internet

\section{GENERATION AND CONNOTATION OF "CULTURAL FEEDBACK"}

According to the latest statistics, the number of internet users in China has reached 632 million and the number of mobile phone internet users has reached 527 million by the end of the first half year of 2014. With the rapid development of internet technology, the number of internet users in China is rising year by year. In considerable internet users, college students are easiest to accept newfangled things. They use the internet as a tool for learning, living and making friends. Besides, they are free to express themselves on the internet and use internet for academic discussion and emotional communication, which have a great help to enrich their knowledge and broaden their horizons and cultivate strong consciousness of their independence. By contrast, because of backward ideas, relatively limited scope of work and more difficulties to accept new things, the ability of ideological and political educators to master and apply network knowledge is poor in many universities and far behind young college students. It is difficult for them to grasp and they simply ignore new ideas, new knowledge brought by internet. It determines that converse education behavior comes into being when college teachers and students communicate with each other. That is to say, the young students become teachers of their teacher.

From the above, "Cultural Feedback" is a derivative of internet development. It means a reverse cultural

Fund project: Social science planning fund project of Liaoning province in 2014 "Discourse innovation research on ideological and political education of universities in network era", serial number: L14CSZ052 transmission way that the older generation learns from the younger generation. As a new type of cultural transmission way, "Cultural Feedback" has become an issue that needs paying close attention to in network era. We call "Occurred in the rapid era of cultural change, the process that the older generation absorb culture widely from the younger generation" [1], the phenomenon that younger generation educate older generation reversely "Cultural Feedback". In the 1970s, American anthropologist Margaret Mead divided the whole human culture into three kinds of basic types, prefigurative culture, con-figurative culture and post-figurative culture in the article of Culture and Commitment-- a Study on the Problem of Generation Gap. In the article, distinguishing from "pre-figurative", younger generation learning from their elders and "co-figurative", peers learning from each other, she use "post-figurative" to generalize the culture propagation and successive model of elders learning from younger people and she emphasizes historical inevitability and social function of the emergence of "post-figurative". In the rapid development of network technology of the $21 \mathrm{st}$ century, the emergence of "Cultural Feedback" is inevitable and the meaning of it will be more plentiful. It has become a characteristic of the era that ideological and political education works have to attach importance to.

\section{THE INFLUENCES OF "CULTURAL FEEDBACK" ON IDEOLOGICAL AND POLITICAL EDUCATION WORK OF UNIVERSITIES}

The development of internet has profound and lasting influences on the society, and so to speak, it is a "doubleedged sword". We cannot simply regard internet as a kind of learning tool. We should treat it as a cultural phenomenon. In the meantime, we should not simply criticize the negative impact that network brings to college students severely. Instead, we should see opportunities and challenges that internet brings to ideological and political education work comprehensively and objectively.

\section{A. Opportunities for Ideological and Political Education Work of Universities in "Cultural Feedback" Era}

Firstly, "Cultural Feedback" promotes the innovation of ideological and political education concept. "Cultural 
Feedback" contributes to broke fixed thinking mode. Under the influence of the students, teachers pay high attention to the relationship between teachers and students and new things and ideas under the network environment and gradually enter new life and new areas of knowledge. Meanwhile, internet development promotes ideological and political education workers to begin to think about how to strengthen ideological and political education for students by using internet. This will bring the change of ideological and political education concept inevitably.

Secondly, "Cultural Feedback" enriches the contents and methods of ideological and political education of universities. In the internet era, the selection of the ideological and political education information has no longer limited in textbooks and reference materials for teaching. Ideological and political educators and college students can take full advantage of internet to share up-to-date information. So the abstract content which is difficult to grasp can express through text, voice, images, animation, films and television content. It improves attraction and actual result of ideological and political work of education in a large extent.

Thirdly, "Cultural Feedback" produces a college student group, of which the students have courage to bring forth new ideas and are full of subject consciousness. Traditional educational mode of ideology and politics overemphasizes that students accept teachers completely and obey the authority, which lead to the phenomenon that young college students are lack of independent consciousness and the spirit of innovation. However, "Cultural Feedback" in internet era makes young college students realize that not only can they accept knowledge from teachers, but also they can have understanding, comprehension, thought and creativity of themselves. Besides, their understanding, thought and creativity have a profound influence on teachers, which improve the students' self-confidence, fully arouse their knowledge and power, inspire them to undertake the historical mission given by the era, and promote the development and progress of society actively. It is the exact result that ideological and political education expectation.

Fourthly, "Cultural Feedback" offsets "generation gap" as well as promotes mutual understanding between teachers and students. "Cultural Feedback" changes relative position between different generations and expanses decision-making power of young students, forming benign interaction between teaching and learning. To a certain extent, "Cultural Feedback" offsets "generation gap" between teachers and students, which is very useful for the ideological and political education of college students.

\section{B. Challenges of Ideological and Political Education Work of Universities in "Cultural Feedback" Era}

Firstly, "Cultural Feedback" is a challenge for the authoritative status of educators. Many platforms such as the internet and mass media provide more opportunities for selfeducation of college students. "Anonymous Elders" such as the internet and mass media have increasing influence on college students and the influence between peers has enlarged in an unprecedented scale, which improve the
"Speaking Right" of college students. Facing the accelerating speed of knowledge update, sometimes students even know earlier than teachers. Teachers lose prior rights of propaganda, education and explanation more or less. This poses a challenge to the authoritative status of educators.

Secondly, "Cultural Feedback" challenges methods of ideological and political education for college students. Now college students are no longer limited to a way of education and they do not simply accept one aspect of education contents any more. The ideological and political education presents the development trend of diversification. Therefore, the method of ideological and political education cannot be limited to classroom teaching, lecture, discussion, social practice and campus culture etc. Emotional communication is indispensable in life. The method of ideological and political education need be adjusted.

Thirdly, "Cultural Feedback" challenges contents of ideological and political education on college students. Now college students are no longer satisfied with rigid theoretical knowledge. They trend to put forward views and opinions of themselves while they feel confused about all kinds of knowledge and information that they acquire. The selection of information by most students is related to world view, level of understanding and ability of themselves and they cannot combine and integrate knowledge and information acquired by them effectively. There is a urgent need for teachers to give relevant guidance and help students form right world view, outlook of life and value view. To do this, ideological and political education needs innovating in content and enlarges amount of information continuously.

Fourthly, "Cultural Feedback" challenges environment of ideological and political education for college students. Contemporary college students absorb plentiful up-to-date information on the internet everyday, which has become a required course in daily study and life. And all kinds of popular culture on college campus have profound influence on college students. The information gets in by every opening and some of them have obvious tendentiousness and unethical and unhealthy characteristics, forming an educational environment adverse to the ideological and political education of college students. Ideological and political educators must draw on advantages and avoid disadvantages in this complex educational environment, exploring a new path actively and optimizing the environment of ideological and political education.

\section{INNOVATION STRATEGY OF IDEOLOGICAL AND POLITICAL EDUCATION WORK IN UNIVERSITIES AND COLLEGES UNDER THE BACKGROUND OF "CULTURAL FEEDBACK"}

\section{A. Changing Educational Concept}

Under the environment of "Cultural Feedback", teachers are no longer the only way of knowledge spreading and students can do everything they can to acquire a good deal of knowledge and information from more ways. Therefore, contemporary college students gradually don't accept knowledge passively but apply knowledge actively. It is 
necessary to update traditional forms of education to modern education form. Under the modern form of education, the subject status of teachers is replaced by students, and teachers lead students to participate in more social practice, know society and integrate into society. The primary mission of teachers undertaking ideological and political education work is to improve the ability of students in learning and self-education and teach students how to survive in a constantly changing environment. Teachers should fully realize the truth that "To teach them fishing is better than give them some fish". Under the modern form of education, teachers as the leader, students as the principal part, teachers guide the students to really go to the "Leading Role" position. To sum up, in order to meet the needs of the development of society better and conform to the situation of "Cultural Feedback" of students, educational concept of teachers in ideological and political education of universities and colleges is in urgent need of updating.

\section{B. Making Full Use of Network Platform and Innovative Education Methods}

Traditional ideological political education constrains students' thought, closes students in an ideal environment, and makes them break away from the real world. In the process of education, "emphasizing theory and neglecting practice", "emphasizing expounding something mechanically and neglecting developing habits", "emphasizing classroom teaching and neglecting extracurricular activities", "emphasizing cultivation and neglecting internalization". However, the result of the phenomenon of "Cultural Feedback" is subsequent change of the measures and methods of ideological and political education. The traditional infusion education has received serious challenge. Therefore, it is necessary to use new information technology to stimulate subject consciousness of the students and motivate their learning enthusiasm for ideological and political theory course. To achieve the purpose of education, ideological and political educators should take full advantage of advanced network technology, such as campus BBS, internet forums, blogs, podcast, micro blogs, emails, chat room and other communication means of network, to strengthen exchange interaction between ideological and political educators and students.

\section{Promoting Knowledge Update and Optimizing the Knowledge Structure}

Knowledge update speed of network society is very fast. If teachers still follow their original knowledge structure and are satisfied with existing knowledge, they cannot adapt to the teaching of the new era inevitably. So teachers engaged in the work of ideological and political education need to set up the idea of lifelong learning, update knowledge continuously, devote themselves to learning advanced thought and theory, educational concept, systematically learn the knowledge of related subjects such as politics, sociology, psychology, management, ethics etc. They must master the theory frontier knowledge of the subject that they teach and can put the latest theory into teaching practice, improving their theoretical quality and scientific cultural quality constantly. Teachers should not only keep learning and enrich themselves, but also can make the best of various media, such as listening to the radio, watching television and surfing the internet etc. They expand aspect of knowledge and update knowledge base through these ways, laying foundation for preparation and organization of teaching content. Only in this way can the knowledge deficit be made up under the environment of "Cultural Feedback" to find the proper way for effective ideological and political education of college students.

\section{Establishing a New-Type Relationship between Teachers and Students}

"Cultural Feedback" is reverse socialization of education industry. Socialization is a bi-directional process and performance of bilateral interaction between teaching and learning in education field. Teaching should be a process of teaching and learning, learning through teaching and teaching by learning. The emergence of the phenomenon of "Cultural Feedback" needs us to relocate and perceive the professional responsibility and social function of ideological and political education again. In the internet era, teachers and students need to switch roles regularly. Therefore, teachers should set up the consciousness of "A man of talent can be regarded as a teacher" with active attitude, learning from students modestly. No matter on or after class, teachers and students can communicate freely and heartily to know each other, learn from each other and make progress together. In real life, in order to enhance mutual understanding between teachers and students, promote the benign development of teaching and obtain better effect of teaching, teachers should have a sincere heart and be amiable to contact with students, create more opportunity to have profound communication with students and care more about students.

\section{E. Enhancing Network Literacy of Ideological and Political Educators}

Through the above analysis, after the phenomenon of "Cultural Feedback" comes into being, means of ideological and political education also has corresponding changes, among them network means has been widely applied. As Mr. Alwan Toffler, a famous American futurologist said, "Those who master the information and control the network will have the entire world." [2] Precisely because of this, the Ministry of Education put forward clearly, "Must develop a team who has a higher level of political theory, be familiar with the law of ideological and political work and the characteristic of network culture, can master network technology and carry out the ideological and political education work on the internet."'[3] It brings forward higher requirements for ideological and political educators, especially emphasizes the cultivation and promotion of network literacy. For ideological and political educators, they should learn high-tech knowledge such as computer and network knowledge actively to improve themselves. For universities and colleges, in order to master more internet technology expertly and improve their internet literacy, they should do their best to train ideological and political theory teachers about network education. 
"Cultural Feedback", a special kind of social phenomenon, has a strong positive significance for social progress, economic growth and the success of students, just as Margaret Mead said, "We can build a future full of vitality only through direct involvement of the younger generation and using extensive and novel knowledge of them.'[4] However, because the thoughts of college students are not mature entirely, they often absorb culture with blindness and random, such as the development of multimedia and network technology make some young college students become "beatles" and "human in capsule" who seclude from the world. Large information flows make some young people lose the ability to distinguish good and bad, and the mistake of identity positioning and anti-social emotion of them come into being. Therefore, ideological and political educators should guide and help students set up the right world outlook, the outlook on life and values with mature mind, rich experience, scientific attitude and keen insight.

\section{REFERENCES}

[1] Zhou Xiaohong. Cultural Feedback: Parent-Child Transmission in Cultural Society [J]. Research on Sociology, 2002(2)

[2] Cheng Changchun. New Theory on Network Ideological Education [M]. Nanjing : Hohai University Press, 2006

[3] Several Opinions of the Ministry of Education on Strengthening the Work That Ideological and Political Education in Institution of Higher Learning Enter the Internet $[\mathrm{J}]$. Political Newspaper of the Ministry of Education, 2000(11)

[4] (America) Margaret Mead. Culture and Commitment--a Study on the Problem of Generation Gap [M]. Translated by Zhou Xiaogong, Zhou Yi. Shijiazhuang: Hebei People's Publishing House, 1987 